\title{
Prevalence and Lifestyle Risk Factors of Overweight and Obesity Among Indonesian Adolescents: An Analysis of Global School-Based Health Survey 2007 and 2015
}

\author{
Prisca Petty Arfines ${ }^{1 *}$, Harry Freitag Luglio ${ }^{2}$, Nunik Kusumawardani ${ }^{1}$ \\ ${ }^{I}$ National Institute of Health Research and Development, Ministry of Health, Jakarta, Indonesia \\ ${ }^{2}$ Faculty of Medicine, Gadjah Mada University, Yogyakarta, Indonesia \\ *Corresponding author.E-mail: prisca.arfines@gmail.com
}

\begin{abstract}
The prevalence of overweight and obesity has doubling globally including Indonesia. Adolescence is a golden period of nutritional intervention in the lifecycle. Objective: This study aimed to examine the prevalence and to identify the associated factors of over nutrition among Indonesian adolescent based on the GSHS data. Methods: This study was a secondary analysis using the GSHS data. Data were collected from 2,343 students (2007) and 11,124 students (2015) which selected based on a two-state cluster sample design. Selfadministered questionnaire and anthropometric measurements were conducted as part of data collection. Over nutrition status was obtained from BMI classification based on the International Obesity Task Force (IOTF) cut off. Multivariate analyses were performed to evaluate the risk factors of overweight and obesity. Results: The prevalence of adolescent overweight and obesity was 8.2\% (CI95\% 6.0-11.2) on 2007 and $14.2 \%$ on 2015 (CI95\% 12.7-15.8). From the 2007 GSHS, the overweight and obesity associated factors were food insecurity (AOR: 2.00; 95\%CI: 1.04-3.84), not walking or biking activity to/from school (AOR: 2.12; 95\% CI: 1.47-3.06) and more sitting activities more than 3 hours (OR: 1.42; 95\%CI: 1.05-1.93). Based on the 2015 GSHS data, factors associated to over nutrition were fruit consumption (AOR: 0.83; 95\%CI: 0.72-0.94) and similar finding on the sitting activities. Sitting activity more than 3 hours a day was strongly associate with overweight and obesity (OR: 1.35; 95\% CI: 1.16-1.57). Interventions to physical activity, healthy diet and behavioral changes were still needed as over nutrition control strategies for Indonesian adolescents.
\end{abstract}

Keywords: overweight, obesity, overnutrition, GSHS, adolescent, Indonesia

\section{INTRODUCTION}

In the past few decades, there is an increasing rate of overweight and obesity among children and adolescents worldwide [1]. According to the Global School-Based Health Survey (GSHS) conducted on period 2007 to 2014, the prevalence of overweight and obesity in Southeast Asian adolescent aged 13-15 years old was 9.9\%. Meanwhile, the trend for adolescent over nutrition in Indonesia has been rising dramatically. The prevalence of overweight and obesity for adolescent aged 13-15 has increased from $2.5 \%$ to $10.8 \%$ and reached $16 \%$, based on National Basic Health Surveys (Riskesdas) year 2010, 2013 and 2018 [2,3,4]. Besides, for adolescent aged 16-18 the prevalence of over nutrition raised from $1.4 \%$ on 2010 to $7.3 \%$ in 2013 and almost doubling to $13.5 \%$ in 2018 $[2,3,4]$.
Interestingly, this rising rate of over nutrition might have reached a plateau in developed worlds but remained increasing in developing and underdeveloped worlds [1,5]. There are some factors that play an important role in slowing down the rate of obesity in developed nations such as the use of tax and regulation of industry [6,7]. It is also important to note the role of local governments, schools, and communities to increase public awareness about overweight and obesity in children and adolescents [1]. Compared to developed countries, the developing countries, especially from Southeast Asian countries, have different conditions that might influence differences in determinants of obesity [5]. Understanding the determinants of obesity is one of the early crucial steps to develop a nationwide obesity prevention program among children and adolescents. 
anthropometrics measurement conducted by the health practitioner. Details on the procedure, methods and questionnaires in the GSHS can be found on the WHO website [12].

The dependent variable of this study was being overweight and obesity. Overweight and obesity status was drawn from Body Mass Index (BMI) calculation. Cut-off point reference on the international age-and sex-specific child and adolescent from IOTF was being used on the categorization for being overweight-or-obese and not overweight-orobese14. In children and adolescent, the BMI cut off points are different form adult. Demographic variable was selfreported age in years and sex. The independent lifestylerelated variables extracted from the original dataset that can be seen in Table 1.

Table 1. Independent Variables Included in the Analysis

\begin{tabular}{|l|l|l|}
\hline Survey question/ variable & Coding (value coded) * & Variable \\
\hline How old are you? & $<11-18+$ years & Age \\
\hline What is your sex? & Male (1) Female (0) & No (0) Yes (1) \\
\hline $\begin{array}{l}\text { Went hungry most of } \\
\text { time/always past 30 days } \\
\text { During the past 30 days, } \\
\text { how many times per day did } \\
\text { you usually eat fruit? } \\
\text { (example provided) }\end{array}$ & $\begin{array}{l}\text { Less than 2 times a day } \\
(1)\end{array}$ & $\begin{array}{l}\text { Fruit } \\
\text { consumption }\end{array}$ \\
\hline $\begin{array}{l}\text { During the past 30 days, } \\
\text { how many times per day did } \\
\text { you usually eat vegetables? } \\
\text { (example provided) }\end{array}$ & $\begin{array}{l}3+\text { times a day (1) } \\
\text { Less than 3 times a day } \\
(0)\end{array}$ & $\begin{array}{l}\text { Vegetable } \\
\text { consumption }\end{array}$ \\
\hline
\end{tabular}
behaviors and several factors including dietary behavior, physical activity, and alcohol use [11,12]. We also would like to analyze the trend of changes in obesity prevalence for adolescents between 2007 and 2015 in Indonesia. By analyzing GSHS data we aimed to evaluate the important determinant lifestyle factors associated with obesity in a nationwide survey.

\section{METHOD}

This study was part of secondary analysis of the 2007 and 2015 Indonesia Global School-based Health Survey. These surveys were collaborative surveillance project between the World Health Organization, the US Centre for Disease Control and the Indonesian Ministry of Health and Ministry of Education [11,13]. Design of this study was cross sectional survey which data were collected in the year 2007 and 2015.

Sample size for the 2007 survey was 3,116 students, while there were 11.110 students participated for the 2015 survey. Sample was selected based on two-stage cluster sample design which selected 49 for 2007 survey and 75 senior and junior high school for 2015 survey using probability proportional sampling in the first stage. The next sampling step was systematic sampling to all classes at selected school. While the class was selected, then all students in that class were eligible to participate in the survey.

Every participant was subjected to self-administered questionnaire which adapted from standardized GSHS questionnaire developed by the WHO with specific modifications. Data were collected using questionnaire and

\begin{tabular}{|c|c|c|}
\hline $\begin{array}{l}\text { During the past } 30 \text { days, } \\
\text { how many times per day did } \\
\text { you usually drink carbonated } \\
\text { soft drinks? (example } \\
\text { provided) }\end{array}$ & $\begin{array}{l}\text { 1+ times a day (1) } \\
\text { Less than } 1 \text { per day }(0)\end{array}$ & $\begin{array}{l}\text { Soft drink } \\
\text { consumption }\end{array}$ \\
\hline $\begin{array}{l}\text { During the past } 7 \text { days, on } \\
\text { how many days did you eat } \\
\text { food from a fast food } \\
\text { restaurant? (example } \\
\text { provided) }\end{array}$ & $\begin{array}{l}3+\text { times a day }(0) \\
\text { Less than } 3 \text { times a day } \\
\text { (1) }\end{array}$ & $\begin{array}{l}\text { Fast food } \\
\text { consumption }\end{array}$ \\
\hline $\begin{array}{l}\text { Physically active for a total } \\
\text { of at least } 60 \text { minutes per } \\
\text { day on } 5 \text { or more days } \\
\text { during the past } 7 \text { days }\end{array}$ & Yes (0) No (1) & $\begin{array}{l}\text { Consistently } \\
\text { physically } \\
\text { active }\end{array}$ \\
\hline $\begin{array}{l}\text { Attending physical } \\
\text { education (PE) class on } 3 \text { or } \\
\text { more days during this }\end{array}$ & $\begin{array}{l}\text { Yes (1) } \\
\text { No (0) }\end{array}$ & PE class \\
\hline $\begin{array}{l}\text { Walk or ride a bicycle to or } \\
\text { from school during the past } \\
7 \text { days }\end{array}$ & $\begin{array}{l}\text { Yes (1) } \\
\text { No }(0)\end{array}$ & $\begin{array}{l}\text { No walking/ } \\
\text { biking to } \\
\text { school }\end{array}$ \\
\hline $\begin{array}{l}\text { How much time do you } \\
\text { spend during a typical or } \\
\text { usual day sitting and } \\
\text { watching television, playing } \\
\text { computer games, talking } \\
\text { with friends, or doing other } \\
\text { sitting activities }\end{array}$ & $\begin{array}{l}<3 \text { hours a day }(0) \\
>=\text { hours a day }(1)\end{array}$ & $\begin{array}{l}\text { Sitting 3+ } \\
\text { hours }\end{array}$ \\
\hline $\begin{array}{l}\text { During the past } 30 \text { days, } \\
\text { how often did you wash } \\
\text { your hands after using the } \\
\text { toilet or latrine? }\end{array}$ & $\begin{array}{l}\text { Most of the time/ } \\
\text { Always (0) } \\
\text { Never/Rarely/Sometime } \\
\text { s (1) }\end{array}$ & $\begin{array}{l}\text { Wash hand } \\
\text { after toilet }\end{array}$ \\
\hline
\end{tabular}




\begin{tabular}{|l|l|l|}
\hline $\begin{array}{l}\text { During the past 30 days, } \\
\text { how often did you wash } \\
\text { your hands before eating? }\end{array}$ & $\begin{array}{l}\text { Most of the time/ } \\
\text { Always (0) } \\
\text { Never/Rarely/Sometime } \\
\text { S (1) }\end{array}$ & $\begin{array}{l}\text { Wash hand } \\
\text { before eating }\end{array}$ \\
\hline $\begin{array}{l}\text { During the past 30 days, on } \\
\text { how many days did you } \\
\text { have at least one drink } \\
\text { containing alcohol? }\end{array}$ & $>=1$ day (1) & $\begin{array}{l}\text { Alcohol } \\
\text { consumption }\end{array}$ \\
\hline
\end{tabular}

*Stata is using lower value (0) as the reference group

Data management and analyses were conducted using STATA software version 13. Regarding the nature of study sampling, data were analyzed using complex sample/ survey data analyses. Declaration on the study design firstly conducted before running out any statistical analyses. Logistic regression was carried out to find the relationship between two variables. Selected variables with $\mathrm{p}$ values $<0.25$ were included in the multivariate analysis. Multivariate logistic regression was performed to determine the predictors of overweight and obesity in the study.

\section{RESULTS AND DISCUSSION}

\section{Results}

Sample characteristics are presented in Table 2. There are differences on the age inclusion between GSHS 2007 and 2015, whereas in 2007 sample were recruited only for school-aged children younger than 16 years old. Total data recorded from 2,343 participants in 2007 and 11,124 participants in 2015 with completeness on weight, height, age and sex. Incompleteness on the anthropometrics measurement was quite high on GSHS 2007 and reached $24.5 \%$ of the total data. The proportion for male and female participants were almost equal. Majority or participants were 13 or 14 years old and in grade 8 or 9 . The prevalence of being overweight and obese were $6.9 \%$ and $1.3 \%$ in 2007, while have increased to $10.3 \%$ and $3.9 \%$ in 2015 .

Table 2. Sample Characteristics

\begin{tabular}{|l|l|c|c|}
\hline \multicolumn{2}{|l|}{ Survey year } & 2007 & 2015 \\
\hline \multicolumn{2}{|l|}{ N (\% missing BMI) } & $2,343(24.5 \%)$ & $11,124(5.1 \%)$ \\
\hline Sex & Male & $49.9 \%$ & $48.9 \%$ \\
& Female & $50.1 \%$ & $51.1 \%$ \\
\hline Age & 11 or younger & $0.3 \%$ & $2.2 \%$ \\
& 12 & $3.6 \%$ & $17.3 \%$ \\
& 13 & $31.1 \%$ & $24.2 \%$ \\
& 14 & $42.2 \%$ & $24.1 \%$ \\
& 15 & $20.2 \%$ & $14.7 \%$ \\
& 16 & $2.7 \%$ & $8.5 \%$ \\
& 17 & $-*$ & $7.5 \%$ \\
& 18 & $-*$ & $1.6 \%$ \\
& & & $25.9 \%$ \\
Grades & 7 & $0.3 \%$ & $25.9 \%$ \\
& 8 & $51.3 \%$ & $25.0 \%$ \\
& 9 & $48.4 \%$ & $6.9 \%$ \\
& 10 & $-*$ & $7.9 \%$ \\
& 11 & $-*$ & $8.4 \%$ \\
& 12 & $-*$ & \\
& & & \\
\hline
\end{tabular}

\begin{tabular}{|l|l|c|c|}
\hline Nutrition & Underweight & $26.8 \%$ & $19.4 \%$ \\
status & Normal weight & $65.0 \%$ & $66.3 \%$ \\
& Overweight & $6.9 \%$ & $10.3 \%$ \\
& Obese & $1.3 \%$ & $3.9 \%$ \\
\hline
\end{tabular}

Adjusted Prevalence of Overweight and Obesity

The prevalence of overweight and obesity was higher for male compare to female respondents $(4.5 \%$ vs $2.4 \%$ and $0.8 \%$ vs $0.5 \%$ ) in 2007 . While in 2015 , the prevalence of overweight switched higher for female than male respondents $(5.6 \%$ vs $4.7 \%)$. However, the obesity prevalence remained higher for male than female $(2.1 \% \mathrm{vs}$ $1.8 \%$ ) (Table 3 ).

Table 3. The Adjusted Prevalence of Overweight and Obesity in 2007 and 2015 by Sex

\begin{tabular}{|l|l|c|c|}
\hline $\begin{array}{l}\text { Year of } \\
\text { Survey }\end{array}$ & \multirow{2}{*}{ Sex } & \multicolumn{2}{|c|}{ Prevalence } \\
\cline { 3 - 4 } & & $\begin{array}{c}\text { Overweight\% } \\
(95 \% \mathrm{CI})\end{array}$ & $\begin{array}{c}\text { Obesity\% (95\% } \\
\mathrm{CI})\end{array}$ \\
\hline 2007 & Male & $4.5(3.0-6.6)$ & $0.8(0.6-1.1)$ \\
\hline & Female & $2.4(1.7-3.4)$ & $0.5(0.2-1.1)$ \\
\hline 2015 & Male & $4.7(4.1-5.5)$ & $2.1(1.6-2.7)$ \\
\hline & Female & $5.6(4.9-6.3)$ & $1.8(1.5-2.1)$ \\
\hline
\end{tabular}

Bivariate Analyses Between Lifestyle-Related Variables and Overweight and Obesity

In bivariate analyses based on the GSHS 2007 data, only walking or biking to school was the only variable which statistically significant with overweight and obesity after controlling sex and age. While according to GSHS 2015, more variables showed significant relationship to overweight and obesity which are fruit consumption, consistently on physical activity, and sitting activity. Details on the ORs can be seen in Table 4.

Table 4. Bivariate Logistic Regression on the Relationship between Lifestyle-Related Variables, Overweight, and Obesity Based On the GSHS 2007 Data

\begin{tabular}{|c|c|c|c|c|c|}
\hline \multirow[t]{3}{*}{ Variable } & \multirow[t]{3}{*}{ Category } & & \multicolumn{2}{|c|}{ GSHS 2007} & \\
\hline & & \multirow{2}{*}{$\begin{array}{c}\text { Adjusted } \\
\text { OR }^{*}\end{array}$} & \multicolumn{2}{|c|}{$95 \% \mathrm{CI}$} & \multirow[t]{2}{*}{$P$} \\
\hline & & & Lower & Upper & \\
\hline \multirow[t]{2}{*}{ Food Insecurity } & Yes & 1.70 & 0.90 & 3.22 & 0.10 \\
\hline & $\mathrm{No}$ & 1 (ref.) & & & \\
\hline \multirow[t]{2}{*}{ Fruit consumption } & $>=2$ times $/$ day & 1 (ref.) & & & \\
\hline & $<2$ times/ day & 1.05 & 0.75 & 1.47 & 0.77 \\
\hline \multirow{2}{*}{$\begin{array}{l}\text { Vegetable } \\
\text { consumption }\end{array}$} & $>=3$ times/ day & 1 (ref.) & & & \\
\hline & $<3$ times/ day & 0.91 & 0.61 & 1.36 & 0.65 \\
\hline $\begin{array}{l}\text { Fast food } \\
\text { consumption }\end{array}$ & $\begin{array}{l}p=3 \\
\text { days/week }\end{array}$ & & $* *$ & & \\
\hline
\end{tabular}




\begin{tabular}{|c|c|c|c|c|c|}
\hline & K 3 days/week & & & & \\
\hline \multirow{2}{*}{$\begin{array}{l}\text { Carbonated soft } \\
\text { drink consumption }\end{array}$} & $P=1$ times $/$ day & & *** & & \\
\hline & $\begin{array}{l}<1 \text { times/day } \\
\end{array}$ & & & & \\
\hline \multirow{2}{*}{\begin{tabular}{|l|} 
Alcohol \\
consumption
\end{tabular}} & Yes & 1.88 & 0.74 & 4.75 & 0.17 \\
\hline & No & 1 (ref.) & & & \\
\hline \multirow{2}{*}{$\begin{array}{l}\text { Consistent } \\
\text { physically active }\end{array}$} & Yes & 1 (ref.) & & & \\
\hline & No & 1.30 & 0.83 & 2.05 & 0.24 \\
\hline \multirow{2}{*}{$\begin{array}{l}\text { PE Class } \\
\text { Attendance }\end{array}$} & Yes, $>=3$ days & & ** & & \\
\hline & No, $<3$ days & & & & \\
\hline \multirow{2}{*}{$\begin{array}{l}\text { Walking/ biking to } \\
\text { and from school }\end{array}$} & Yes & 1 (ref.) & & & \\
\hline & No & 2.10 & 1.42 & 3.12 & 0.001 \\
\hline \multirow[t]{2}{*}{ Sitting activities } & $\begin{array}{l}>=3 \text { hours/ } \\
\text { day }\end{array}$ & 1 (ref.) & & & \\
\hline & $<3$ hours/day & 1.32 & 0.93 & 1.87 & 0.12 \\
\hline \multirow[t]{2}{*}{ Cigarette smoking } & Yes & 0.91 & 0.74 & 1.71 & 0.57 \\
\hline & No & 1 (ref.) & & & \\
\hline \multirow{2}{*}{$\begin{array}{l}\text { Used other tobacco } \\
\text { product }\end{array}$} & Yes & & $* *$ & & \\
\hline & No & & & & \\
\hline \multirow{2}{*}{$\begin{array}{l}\text { Handwash before } \\
\text { eating }\end{array}$} & Yes & 1 (ref.) & & & \\
\hline & No & 1.12 & 0.70 & 1.79 & 0.62 \\
\hline \multirow{2}{*}{$\begin{array}{l}\text { Handwash after } \\
\text { toilet }\end{array}$} & Yes & 1 (ref.) & & & \\
\hline & No & 1.09 & 0.67 & 1.76 & 0.71 \\
\hline
\end{tabular}

Table 5. Bivariate Logistic Regression on the Relationship between Lifestyle-Related Variables, Overweight, and Obesity Based On the GSHS 2007 Data

\begin{tabular}{|c|c|c|c|c|c|}
\hline \multirow[t]{3}{*}{ Variable } & \multirow[t]{3}{*}{ Category } & & \multicolumn{2}{|c|}{ GSHS 2015} & \\
\hline & & \multirow{2}{*}{$\begin{array}{c}\text { Adjusted } \\
\text { OR* }\end{array}$} & \multicolumn{2}{|c|}{$95 \% \mathrm{CI}$} & $P$ \\
\hline & & & Lower & Upper & \\
\hline \multirow[t]{2}{*}{ Food Insecurity } & Yes & 0.84 & 0.58 & 1.21 & 0.34 \\
\hline & No & 1 (ref.) & & & \\
\hline \multirow[t]{2}{*}{ Fruit consumption } & $>=2$ times/ day & 1 (ref.) & & & \\
\hline & $<2$ times/day & 0.82 & 0.72 & 0.92 & 0.002 \\
\hline \multirow{2}{*}{$\begin{array}{l}\text { Vegetable } \\
\text { consumption }\end{array}$} & $>=3$ times $/$ day & 1 (ref.) & & & \\
\hline & $<3$ times/ day & 0.96 & 0.84 & 1.09 & 0.51 \\
\hline \multirow[t]{2}{*}{$\begin{array}{l}\text { Fast food } \\
\text { consumption }\end{array}$} & $\begin{array}{l}p=3 \\
\text { days/week }\end{array}$ & 1 (ref.) & & & \\
\hline & < 3 days/week & 1.03 & 0.85 & 1.25 & 0.76 \\
\hline
\end{tabular}

\begin{tabular}{|l|l|c|c|c|c|}
\hline $\begin{array}{l}\text { Carbonated soft } \\
\text { drink consumption }\end{array}$ & $>=1$ times/day & 0.99 & 0.88 & 1.12 & 0.84 \\
\cline { 2 - 6 } & $<1$ times/day & 1 (ref.) & & & \\
\hline $\begin{array}{l}\text { Alcohol } \\
\text { consumption }\end{array}$ & Yes & 0.75 & 0.55 & 1.02 & 0.06 \\
\cline { 2 - 6 } & No & 1 (ref.) & & & \\
\hline $\begin{array}{l}\text { Consistent } \\
\text { physically active }\end{array}$ & Yes & 1 (ref.) & & & \\
\cline { 2 - 6 } & No & 0.86 & 0.74 & 0.99 & 0.04 \\
\hline $\begin{array}{l}\text { PE Class } \\
\text { Attendance }\end{array}$ & Yes, >=3 days & 1 (ref.) & & & \\
\cline { 2 - 6 } & No, <3 days & 1.16 & 0.98 & 1.38 & 0.09 \\
\hline $\begin{array}{l}\text { Walking/ biking to } \\
\text { and from school }\end{array}$ & Yes & 1 (ref.) & & & \\
\cline { 2 - 6 } & No & 0.98 & 0.85 & 1.14 & 0.84 \\
\hline Sitting activities & $>=3$ hours/ & 1 (ref.) & & & \\
\cline { 2 - 6 } & day & & & & \\
\cline { 2 - 6 } & $<3$ hours/ day & 1.32 & 1.14 & 1.54 & 0.001 \\
\hline
\end{tabular}

*adjusted for sex and age

**not available in this year's survey; PE: physical exercise

Lifestyle-Related Risk Factors for Overweight and Obesity

Risk factors for overweight and obesity based on the multivariate logistic regression were presented in Table 5 and 6. Based on the GSHS 2007 data analyses found that adolescents with food insecurity (OR: 2.00; 95\%CI: 1.043.84), not walking/ biking to school (OR: 2.12 ; $95 \% \mathrm{CI}$ : 1.47-3.06) and spend more time for sitting activity more than 3 hours (OR: 1.42; 95\%CI: 1.05-1.93) were associated with overweight and obesity. Whereas according to the GSHS 2015 revealed that adolescents who consume fruit 2 or more portion a day were $17 \%$ less likely to become overweight or obese (OR: 0.83; 95\%CI: 0.72-0.94). Similar to the GSHS 2007 analyses found that sitting activity more than 3 hours a day was strongly associate with overweight and obesity (OR: 1.35; 95\%CI: 1.16-1.57).

Table 6. Multiple Logistic Regression of Lifestyle-Related Risk Factors of Adolescent Overweight and Obesity Based On the GSHS 2007 Data

\begin{tabular}{|l|c|c|c|c|}
\hline Variable & \multirow{2}{*}{$\begin{array}{l}\text { Adjusted } \\
\text { OR }\end{array}$} & \multicolumn{2}{|c|}{ GSHS 2007 } & \multirow{2}{*}{} \\
\cline { 3 - 4 } & & \multicolumn{2}{|c|}{$95 \%$ CI } & \\
\cline { 3 - 4 } & & Lower & Upper & \\
\hline Food Insecurity & 2.00 & 1.04 & 3.84 & 0.04 \\
\hline Alcohol consumption & 1.37 & 0.52 & 3.61 & 0.50 \\
\hline $\begin{array}{l}\text { Consistent physically } \\
\text { active }\end{array}$ & 1.30 & 0.81 & 2.09 & 0.27 \\
\hline $\begin{array}{l}\text { Walking/ biking to } \\
\text { and from school }\end{array}$ & 2.12 & 1.47 & 3.06 & $<0.001$ \\
\hline Sitting activities & 1.42 & 1.05 & 1.93 & 0.02 \\
\hline $\begin{array}{l}\text { Used other tobacco } \\
\text { product }\end{array}$ & 1.90 & 0.93 & 3.90 & 0.08 \\
\hline
\end{tabular}


Table 7. Multiple Logistic Regression of Lifestyle-Related Risk Factors of Adolescent Overweight and Obesity Based On the GSHS 2015 Data

\begin{tabular}{|l|c|c|c|c|}
\hline \multirow{2}{*}{$\begin{array}{l}\text { Variable } \\
\text { OR }\end{array}$} & & \multicolumn{2}{|c|}{ GSHS 2015 } & \multirow{2}{*}{} \\
\cline { 3 - 4 } & \multicolumn{2}{|c|}{$95 \%$ CI } & \multirow{2}{*}{} \\
\cline { 3 - 4 } & Lower & Upper & \\
\hline Fruit consumption & 0.83 & 0.72 & 0.94 & 0.005 \\
\hline Alcohol consumption & 0.78 & 0.58 & 1.04 & 0.09 \\
\hline $\begin{array}{l}\text { Consistent physically } \\
\text { active }\end{array}$ & 0.89 & 0.77 & 1.03 & 0.11 \\
\hline PE Class Attendance & 1.12 & 0.93 & 1.34 & 0.23 \\
\hline Sitting activities & 1.35 & 1.16 & 1.57 & $<0.001$ \\
\hline $\begin{array}{l}\text { Used other tobacco } \\
\text { product }\end{array}$ & 0.69 & 0.37 & 1.27 & 0.23 \\
\hline
\end{tabular}

\section{Discussion \\ Prevalence of Overweight and Obesity}

This study presents the prevalence of overweight and obesity based on two national representative adolescent health surveys using the IOTF BMI cutoffs. There has been a dramatic change on the prevalence of overweight and obesity between those survey periods $(8.20 \%$ in 2007 to $14.20 \%$ in 2015 . While based on GSHS 2007 data reported the prevalence was $7.0 \% 15$ and has increase to $13.4 \%$ in 201513. These numbers are similar to the result of Riskesdas, which depicted the prevalence that almost doubling for adolescent aged 16-18 years old (7.3\% in 2013 to $13.5 \%$ in 2018 ) in the last 6 years $[3,16]$. Whereas the increment on the prevalence for adolescent aged 13-15 years old quite high, accounted to $5.2 \%$ difference in 5 years (10.8\% in 2013 to $16 \%$ in 2018$)$ [3,16].

The prevalence difference between various surveys due to differences on their study design, sampling methods, also in inclusion and exclusion criteria. Despite the difference between the exact prevalence rates of overweight and obesity in Indonesian adolescents, all references showed a significant upward trend. This should be the focus of the Indonesian government in controlling overweight and obesity.

According to a systematic review based on both cohort studies and observational studies found the relationship between childhood-adolescent overweight and obesity with premature death in particular on cardio metabolic morbidity in later life [17]. Even though this evidence comes from developed countries, but a longitudinal study taken place in Indonesia found a consistent result. Tracking on the children's BMI over 5 years found that $84.6 \%$ overweight children turned into overweight adolescent and all obese children remained as obese adolescent [9]. For a number of reasons, to date the topic of overweight and obesity in adolescents has not been the focus of government programs. In particular, in developing countries, where many other health problems take precedence. However, this evidence shows the urgency on the policy-maker to invest more on adolescent weight control on lowering the risk of premature death related to cardio metabolic in the future.

\section{Risk Factors of Overweight and Obesity}

Multivariate analyses on the GSHS 2007 and 2015 found different lifestyle-related risk factors on adolescent's overweight and obesity. Only sitting activities contributes to overweight and obesity on both GSHS's surveys. Sitting activity represents the sedentary lifestyle. Consistent with other GSHS data analysis comes form 7 Southeast Asian countries which found a high prevalence of physical inactivity $(80.4 \%)$ and sedentary activity $(33.0 \%)$. There has been growing evidence on the relationship between childhood and adolescent sedentary activity along with physical in-activity as overweight and obesity risk factors $[5,18,10,19]$. According to GSHS 2007 data, the odds of student who did not walking/ biking from and to school was twice times higher to be overweight or obese. The mechanism of physical inactivity and dietary contribution to overweight and obesity may happen through 3 different ways: decreasing on energy expenditure, increasing energy intake through snacking and reduction in resting metabolic rate [20].

Regarding dietary contribution along others dietary risky behaviors, only fruit consumption showed as protective factors to overweight and obesity. Unhealthy diet was common in adolescent with the preference mostly on sugarsweetened beverages, sweet, salty and fatty food [21]. Currently, Indonesia is experiencing the nutrition transition, where there has been changes on the food preferences shifting from traditional diet to modern yet highly in fat, sugar and salty foods. Moreover, with decreasing consumption on fruit and vegetables [22]. Only $23.22 \%$ of Indonesian adolescents have met the reference for daily fruit consumption [13]. A literature suggested on the behavior of eating family dinner or food that being prepared at home. This promotes healthier food choices on fruit and vegetable consumption, less fried foods and sugarsweetened foods [21].

Another risk factor determined in this study was food insecurity. Food insecurity is a situation where an adolescent is experiencing a limited access to sufficient, safe and nutritious food to meet their nutritional requirement to grow and live a healthy life [23]. A longitudinal study found that food insecurity experience at the age 15 years old tend to accelerate the BMI in later life [24]. This relationship may be explained through some potential factors, such as low socioeconomic status, low knowledge and education resulted on the poor food preferences and increase the risk on overweight and obesity $[24,25]$.

\section{Strengths and limitations}

The main strength in present study was using nationalrepresentative surveys on adolescent health that were globally comparable. Some limitations on this study need to be acknowledged. First, this study was cross-sectional which the causality cannot be established. Secondly, due to self-administered questionnaire may lead to high response bias. However, the GSHS questionnaire reported as standardized, rapid, cost-effective and useful surveillance instrument to capture adolescent's health behaviors. Third, regarding the BMI missing value in GSHS 2007 data that 
[8] Maehara M, Rah JH, Roshita A, Suryantan J,

quite high. This should be taken into account on the generalizability. Reference usage also resulted on difference prevalence rates on overweight and obesity. Currently there are 3 references that globally used: WHO BMI z-score, IOTF BMI cut-offs and CDC percentile [26].

\section{CONCLUSION}

In summary, this study presents the urgency on adolescent health intervention as part of overweight and obesity control. There has been a dramatic increasing on overweight and obesity prevalence in the last 6 years. Interventions to physical activity, healthy diet and behavioral changes were still needed as over nutrition control strategies for Indonesian adolescents. To date, programs to prevent adolescent obesity have so far remained limited and less likely to be prioritized. The rapid increase in over nutrition prevalence called for serious interventions involving multisetting approach by schools, families, communities, government and markets. Interventions should not be only limited to the promotion of healthy lifestyles. Policies such as taxes on sugar sweetened beverages should also put into consideration to be implemented in the future.

\section{REFERENCES}

[1] Bentham J, Di Cesare M, Bilano V, Bixby H, Zhou B, Stevens GA, et al. Worldwide trends in bodymass index, underweight, overweight, and obesity from 1975 to 2016: a pooled analysis of 2416 population-based measurement studies in $128 \cdot 9$ million children, adolescents, and adults. Lancet. 2017;390(10113):2627-42.

[2] Badan Penelitian dan Pengembangan Kesehatan Kementerian RI. Riset Kesehatan Dasar (RISKESDAS) 2010. Jakarta; 2010.

[3] Badan Penelitian dan Pengembangan Kesehatan Kementerian RI. Riset Kesehatan Dasar RISKESDAS 2013 [Internet]. Jakarta; 2013.

[4] Badan Penelitian dan Pengembangan Kesehatan Kementerian RI. Laporan Nasional Riskesdas 2018. Jakarta; 2019.

[5] Gupta N, Goel K, Shah P, Misra A. Childhood obesity in developing countries: Epidemiology, determinants, and prevention. Endocr Rev. 2012;33(1):48-70.

[6] Kraak VI, Vandevijvere S, Sacks G, Brinsden H, Hawkes C, Barquera $S$, et al. Progrès réalisés pour restreindre la commercialisation d'aliments et de boissons riches en graisses, en sucre ou en sel destinés aux enfants. Bull World Health Organ. 2016;94(7):540-8.

[7] Hawkes C, Harris JL. An analysis of the content of food industry pledges on marketing to children. Public Health Nutr. 2011;14(8):1403-14. Rachmadewi A, Izwardy D. Patterns and risk factors of double burden of malnutrition among adolescent girls and boys in Indonesia. PLoS One. 2019;14(8): e0221273.

[9] Julia M, Van Weissenbruch MM, Prawirohartono EP, Surjono A, Delemarre-van De Waal HA. Tracking for underweight, overweight and obesity from childhood to adolescence: A 5-year follow-up study in urban Indonesian children. Horm Res. 2008;69(5):301-6.

[10] Collins AE, Pakiz B, Rock CL. Factors associated with obesity in Indonesian adolescents. Int J Pediatr Obes. 2008;3(1):58-64.

[11] Indonesia Ministry of Health, Ministry of Education, The World Health Organization, US Centers for Disease Control and Prevention. Global School-Based Student Health Survey (GSHS) Indonesia [Internet]. 2007. Available from: https://www.cdc.gov/gshs/countries/seasian/indone sia.htm

[12] World Health Organization. Noncommunicable diseases and their risk factors: Global school-based student health survey (GSHS) [Internet]. 2018 [cited 2019 Oct 7]

[13] Kusumawardani N, Soerachman R, Wiryawan Y, Anwar A, Handayani K, Mubasyiroh R, et al. Perilaku Berisiko Kesehatan Pada Pelajar SMP dan SMA di Indonesia [Internet]. Jakarta; 2015. Available from: https://www.cdc.gov/gshs/countries/seasian/indone sia.htm

[14] Cole TJ, Lobstein T. Extended international (IOTF) body mass index cut-offs for thinness, overweight and obesity. Pediatr Obes. 2012;7(4):284-94.

[15] Pengpid S, Peltzer K. Overweight, obesity and associated factors among 13-15 years old students in the association of Southeast Asian Nations member countries, 2007-2014. Southeast Asian J Trop Med Public Health. 2016;47(2):250-61.

[16] Badan Penelitian dan Pengembangan Kesehatan Kementerian RI. Hasil utama riskesdas 2018 [Internet]. 2018. Available from: http://www.depkes.go.id/resources/download/infoterkini/materi_rakorpop_2018/Hasil Riskesdas 2018.pdf

[17] Reilly JJ, Kelly J. Long-term impact of overweight and obesity in childhood and adolescence on morbidity and premature mortality in adulthood: Systematic review. Int J Obes. 2011;35(7):891-8.

[18] Peltzer K, Pengpid S. Leisure Time Physical Inactivity and Sedentary Behaviour and Lifestyle Correlates among Students Aged 13 - 15 in the Association of Southeast Asian Nations (ASEAN ) Member States , 2007 - 2013. 2013;1-15.

[19] Prentice-dunn H, Prentice-dunn S. Physical activity, sedentary behavior, and childhood obesity: A 
review of cross-sectional studies. (June 2013):3741.

[20] Ziyagil MA, Ox P. The relationships among obesity, physical activity, the knowledge level about obesity, watching food ads on TV with interest, and the number of weekly school canteen usage in adolescents. 2011; 28:591-5.

[21] Taylor P, Moreno LA, Rodríguez G, Bueno G, Bueno-lozano M, Azaro AL. Trends of Dietary Habits in Adolescents Trends of Dietary Habits in. 2010; (June 2013):37-41.

[22] Popkin BM. Rank Prize Lecture Contemporary nutritional transition: determinants of diet and its impact on body composition Proceedings of the Nutrition Society. 2019;(November 2010):82-91.

[23] Food and Agriculture Organization. Food Security: Policy Brief [Internet]. 2006. Available from: http://www.fao.org/fileadmin/templates/faoitaly/do cuments/pdf/pdf_Food_Security_Cocept_Note.pdf

[24] Lohman BJ, Neppl TK, Lee Y, Diggs ON, Russell D. The Association between Household Food Insecurity and Body Mass Index: A Prospective Growth Curve Analysis. J Pediatr [Internet]. 2018; 202:115-120.e1. Available from: https://doi.org/10.1016/j.jpeds.2018.05.052

[25] Mohammad A, Ajami M, Abdollahi M, Ahari GK. A Review of the Relationship between Obesity and Food Insecurity. 2016;3(1):381-8.

[26] Manyanga T, El-sayed H, Doku DT, Randall JR. The prevalence of underweight, overweight, obesity and associated risk factors among school-going adolescents in seven African countries. 2014;1-11. 